\title{
MiRNA-143 mediates the proliferative signaling pathway of FSH and regulates estradiol production
}

\author{
Li Zhang ${ }^{1 *}$, XiaoXin Zhang²*, Xuejing Zhang', Yu Lu', Lei Lí2 and Sheng Cui' \\ 'State Key Laboratory of Agrobiotechnology, College of Biological Sciences, China Agricultural \\ University, People's Republic of China \\ 2State Key Laboratory of Stem Cell and Reproductive Biology, Institute of Zoology, Chinese Academy of \\ Sciences, China University of Chinese Academy of Sciences, Beijing, People's Republic of China \\ *(L Zhang and X Zhang contributed equally to this work)
}

Correspondence should be addressed to $S$ Cui Email cuisheng@cau.edu.cn

\begin{abstract}
MicroRNAs (MiRNAs) play important regulatory roles in many cellular processes. MiR143 is highly enriched in the mouse ovary, but its roles and underlying mechanisms are not well understood. In the current study, we show that miR-143 is located in granulosa cells of primary, secondary and antral follicles. To explore the specific functions of miR143 , we transfected miR-143 inhibitor into primary cultured granulosa cells to study the loss of function of miR-143 and the results showed that miR-143 silencing significantly increased estradiol production and steroidogenesis-related gene expression. Moreover, our in vivo and in vitro studies showed that follicular stimulating hormone (FSH) significantly decreased miR-143 expression. This function of miR-143 is accomplished by its binding to the $3^{\prime}$-UTR of KRAS mRNA. Furthermore, our results demonstrated that miR-143 acts as a negative regulating molecule mediating the signaling pathway of FSH and affecting estradiol production by targeting KRAS. MiR-143 also negatively acts in regulating granulosa cells proliferation and cell cycle-related genes expression. These findings indicate that miR-143 plays vital roles in $\mathrm{FSH}$-induced estradiol production and granulosa cell proliferation, providing a novel mechanism that involves miRNA in regulating granulosa cell functions.
\end{abstract}
Key Words
- MiR-143
- ovary
- estradiol
- proliferation
- kRAS

- $\mathrm{FSH}$

\section{Introduction}

Follicles are the functional units of the ovary that consist of oocytes and one or more layers of somatic granulosa cells. Ovarian follicular development is dependent on the proliferation and differentiation of the granulosa cells (Craig et al. 2007), and the estradiol synthesized from the granulosa cells is required for the structure and function of female reproductive tissues. Many extra- and intra-ovarian factors have been implicated in granulosa cell proliferation and estradiol synthesis, such as the pituitary gonadotropin, including the follicular stimulating hormone (FSH) and luteinizing hormone (LH) (Frishman et al. 1992).

MicroRNA (miRNA) are conserved, short noncoding RNAs (19-25bp) that act as important cellular regulators, influencing cell proliferation, apoptosis and differentiation (Mattes et al. 2007, Farazi et al. 2008). MiRNA precursors (pre-miRNAs) are generated in the nucleus, and are then cleaved to a mature functional miRNA by Dicer, the ribonuclease 3 (Hong et al. 2008). Mature miRNAs bind the 3'-untranslated regions

Published by Bioscientifica Ltd. 
(3'-UTR) of target mRNAs thus promoting targeted mRNA degradation, translational repression or both (Stefani \& Slack 2006, Sirotkin et al. 2009).

The role of miRNA in mammalian reproduction has been explored in several studies. It has been reported that Dicer is expressed in both oocytes and granulosa cells of the mouse ovary's follicle (Lei et al. 2010). Conditional inactivation of Dicer1 in follicular granulosa cells leads to increased primordial follicle pool endowment and accelerates early follicle recruitment. More degenerated follicles have been found in Dicer1 KO mouse ovaries. (Hong et al. 2008). In addition, significant differences between KO and WT mouse ovaries were noted in the expression of certain follicle development-related genes, such as CYP19A1, which is the gene that encodes aromatase (Hong et al. 2008, Nagaraja et al. 2008, Stocco 2008), indicating that miRNAs are mechanistically involved in ovarian functions.

MiR-143 is a short RNA molecule, which is highly conserved in vertebrates (Song et al. 2011). Functional studies of miR-143 have been mainly focused on cardiac morphogenesis and cancer tissues (Chen et al. 2009, Wu et al. 2013). It has been documented that miR-143 suppresses the development of cancers by inhibiting cell proliferation (Xu et al. 2011a) and that miR-143 expression is reduced in several types of tumors, including colorectal cancer (Chen et al. 2009), prostate cancer (Clape et al. 2009) and human ovarian cancer (Iorio et al. 2007b).

Under normal physiological conditions, miR-143 is expressed in pregranulosa cells during primordial follicle formation which occurs between $17.5 \mathrm{dpc}$ and approximately $4-5 \mathrm{dpp}$, and is also expressed in granulosa cells of primary, secondary and antral follicles in the mouse ovary. These cells participate in murine primordial follicle formation (Zhang et al. 2013) and play roles in FSH-induced folliculogenesis (Yao et al. 2009).

The V-Ki-ras2 Kirsten rat sarcoma viral oncogene homolog, also known as KRAS, is a key molecule in the EGFR/RAS/mitogen-activated protein kinase (MAPK) pathway (Malumbres \& Barbacid 2003). KRAS has been found to be associated with cell proliferation and migration in response to growth factors (Downward 2003). Previous studies revealed that KRAS is a direct target of miR-143 in colorectal tumorigenesis and prostate cancer (Chen et al. 2009, Xu et al. 2011a).

In the present study, we found that miR-143 is mainly expressed in mouse ovarian granulosa cells and functions as a mediator of the FSH signaling pathway to regulate estradiol synthesis and secretion by targeting KRAS.
Additionally, miR-143 is critical in regulating the cell proliferation in ovarian granulosa cells.

\section{Materials and methods}

\section{Animals}

Mice for this study were purchased from the Animal Institute of the Chinese Medical Academy (Beijing, China) and raised in standard temperature $\left(25 \pm 1^{\circ} \mathrm{C}\right)$ and light (12 h light, $12 \mathrm{~h}$ darkness cycle) conditions. All animal procedures were approved by the Chinese Association for Laboratory Animal Sciences. Female mice (Kun Ming white) at approximately 21 days were injected intraperitoneally with $10 \mathrm{U}$ of pregnant mare serum gonadotropin (PMSG) to stimulate follicular development.

\section{In situ hybridization (ISH)}

MiR-143 ISH was carried out by using digoxigeninlabeled locked nucleic acid (LNA) probes. Mmu-MiR143-3p miRCURY LNA microRNA detection probes (TGAGCTACAGTGCTTCATCTCA) and scrambled probes (CATTAATGTCGGACAACTCAAT) were purchased from Exiqon (MA, USA). The LNA probes were labeled with digoxingenin using a DIG oligonucleotide tailing kit (Roche) following the manufacturer's instructions. After the ovaries were collected, all of the samples were fixed in $4 \%$ paraformaldehyde (PFA) in phosphate-buffered saline (PBS) treated with diethyl pyrocarbonate. The cryosections (10 $\mu \mathrm{m}$ thick) were prepared, and ISH was carried out as described previously (Obernosterer et al. 2007). The sections were examined under a DMRB light microscope (Leica).

\section{Isolation of granulosa cells and cell culture}

Granulosa cell isolation was performed as described previously (Hanoux et al. 2007, Fiedler et al. 2008, Teng et al. 2015). The ovaries were cleaned of the surrounding marginal tissue under a stereomicroscope and washed twice with DMEM/F12 medium. Granulosa cells were collected immediately by puncturing follicles from the isolated ovary, which had been cleaned as above with a 25-gauge needle in a Falcon dish. Granulosa cell suspensions were then centrifuged at $1200 \boldsymbol{g}$ for $5 \mathrm{~min}$ and resuspended in DMEM/F12 medium supplemented with $10 \%$ fetal bovine serum (FBS) (GIBICO, Carlsbad, CA, USA), $100 \mathrm{IU} / \mathrm{ml}$ penicillin and $100 \mu \mathrm{g}$ streptomycin

Published by Bioscientifica Ltd 
sulfate. The cells were then counted, and viability was assessed. For the assay, cells were plated $\left(1.0 \times 10^{5}\right.$ cells/ well) onto 6-well plates for $24 \mathrm{~h}$ at $37^{\circ} \mathrm{C}$ in a humidified atmosphere of $5 \% \mathrm{CO}_{2}$. After being cultured for $48 \mathrm{~h}$, the primary granulosa cells were transfected.

\section{MicroRNA and siRNA transfections}

The transfections of the miR-143 inhibitor or mimics (Shanghai GenePharma Co., Ltd, China) were performed using Lipofectamine 2000 (Invitrogen) according to the manufacturer's instructions. Six hours after transfection, the cells were collected for real-time PCR (RT-PCR) or cell proliferation analysis. The following oligos were used for cell transfection: NC-inhibitor (NC-in) (5'CAGUaCUUUUGUGUAGUACAA3); mmu-miR-143 inhibitor (5'-GAGCUACAGUGCUUCAUCUCA-3); mmumiR-143 mimics (5'-UGAGAUGAAGC ACUGUAGCUC-3', Reverse:5'-GCUACAGUGCUUCAUCUCAUU-3);NC-mimics (NC -mi) (Forward: 3'-UUCUCCGAACGUGUCACGUTT-3', Reverse: 5'- ACGUGACACGUUCGGAGA ATT-3).

\section{Real-time PCR}

According to the protocol provided by the manufacturer, the total RNA of the granulosa cells was isolated using the Trizol Reagent (Takara, Tokyo, Japan). U6 RNA was used for normalization of microRNA expression. Reverse transcriptase reactions contained the purified total RNA $(0.3 \mu \mathrm{g})$ and $50 \mathrm{nM}$ RT primer (the RT-miR-143 stem-loop primer: CTCAACTGGTGTCGTGGAGTCGGCAATTC AGTTGAGGAGCTACA and the RT-U6 stem-loop primer: AACGCTTCACGAATTTGCGT). M-MLV Reverse Transcriptase (Promega) was used according to the manufacturer's instructions. The $15 \mu \mathrm{L}$ reactions were incubated in a DNA Thermal Cycler 4800 for $30 \mathrm{~min}$ at $16^{\circ} \mathrm{C}, 30 \mathrm{~min}$ at $42^{\circ} \mathrm{C}$ and $5 \mathrm{~min}$ at $85^{\circ} \mathrm{C}$. Real-time PCR was performed using a standard Takara SYBR Premix Ex Taq protocol on an Applied Biosystems 7500 Real-time PCR System (Applied Biosystems). The primer sequences are listed in Table 1, and the conditions were as follows: $95^{\circ} \mathrm{C}$ for $10 \mathrm{~min}$, followed by 40 cycles of $95^{\circ} \mathrm{C}$ for $15 \mathrm{~s}$ and $60^{\circ} \mathrm{C}$ for $1 \mathrm{~min}$. The relative abundance of the genes was determined using the 2- $\Delta \Delta C$ T method (Schmittgen 2001) with GAPDH as the reference gene using ABI PRISM 7500 equipped software (Applied Biosystems). All the experiments were performed in at least triplicate. The validation
Table 1 Sequences of the primers applied for real-time PCR.

\begin{tabular}{|c|c|}
\hline Gene & Sequence of primers $\left(5^{\prime} \rightarrow 3^{\prime}\right)$ \\
\hline \multirow[t]{2}{*}{ Cyclin B1 } & F: TGGCCTCACAAAGCACATGA \\
\hline & R: GCTGTGCCAGCGTGCTAATC \\
\hline \multirow[t]{2}{*}{ Cyclin D2 } & F: AAGCCTGCCAGGAGCAAA \\
\hline & R: ATCCGGCGTTATGCTGCTCT \\
\hline \multirow[t]{2}{*}{ Cyclin E2 } & F: TGCTGCCGCCTTATGTCATT \\
\hline & R: TCCGAGATGTCATCCCATTCC \\
\hline \multirow[t]{2}{*}{$C d k 4$} & F: GGCCTTTGAACATCCCAAT \\
\hline & R: TCAGTTCGGGAAGTAGCACAG \\
\hline \multirow[t]{2}{*}{ Kras } & F:TGAGGACTGGATGTCTGTCT \\
\hline & R:CACGGCTGGGAGGTTAATGT \\
\hline \multirow[t]{2}{*}{$C d k 6$} & F: AGGAGGCTATAAAGGACACC \\
\hline & R: AGGAGGCTATAAAGGACACC \\
\hline \multirow{2}{*}{ Star } & F: AGTCCTTCGAACACCGATGA \\
\hline & R: GTCTTGCTATGCCTTCTTTGG \\
\hline \multirow[t]{2}{*}{ 3B-hsd } & F: CACTTGTCAACTGGGAGG \\
\hline & R: CAGAAAGCAACGGGATT \\
\hline \multirow[t]{2}{*}{ P450scc } & F: AGGTGTAGCTCAGGACTTCA \\
\hline & R: AGGAGGCTATAAAGGACACC \\
\hline \multirow[t]{2}{*}{ Сур19a1 } & F: CATTTTATCGAGTAGGTGGCG \\
\hline & R: AGGATTGGTCCTTTAAGGCTT \\
\hline \multirow[t]{2}{*}{$17 B-h s d 1$} & F: GACCGTTCCCAGAGCTTCAA \\
\hline & R: CAGCACCCACAGCGTTCAAT \\
\hline \multirow[t]{2}{*}{ U6 } & F: CTCGCTTCGGCAGCACA \\
\hline & R: AACGCTTCACGAATTTGCGT \\
\hline \multirow[t]{2}{*}{ GAPDH } & F:GGTTGTCTCCTGCGACTTCA \\
\hline & R:GGGTGGTCCAGGGTTTCTTA \\
\hline
\end{tabular}

$F$, forward primer; $R$, reverse primer.

of the real-time PCR assays were conducted, and the results were showed in the Supplementary Figure 1 (see section on supplementary data given at the end of this article).

\section{BrdU analysis}

After transfecting with inhibitors and mimics and cultured as above, the granulosa cells were further cultured with 5'-bromo-2'-deoxy-uridine (BrdU, final concentration $20 \mu \mathrm{g} / \mathrm{ml}$ ) for $3 \mathrm{~h}$. They were then fixed, permeabilized and treated with $10 \%$ goat serum and incubated with G3G4 (1:50, Developmental Studies Hybridoma Bank, University of Iowa). The sections were then incubated with biotinylated goat anti-mouse IgG and HRPconjugated streptavidin (1:500, Jackson ImmunoResearch Laboratories, Inc., West Grove, PA, USA) at RT for $2 \mathrm{~h}$. Visualization was done using diaminobenzidine (DAB) with hematoxylin counterstaining. At least five random fields per well were counted for the labeled cells in three separate experiments. The BrdU labeling index was defined as the ratio of the number of BrdU-positive nuclei to the number of total nuclei within the fields. (c) 2017 Society for Endocrinology Printed in Great Britain 


\section{Radioimmunoassay (RIA)}

Transfected granulosa cells were cultured in FBS-free DMEM/F12 (phenol red-free) medium for $24 \mathrm{~h}$. The medium was then collected for measuring estradiol and progesterone levels, and the cells were lysed in $1 \mathrm{~mL}$ Trizol for gene determination. Estradiol/progesterone radioimmunoassay reagents were provided by the Beijing North Institute Biological Technology (Beijing, China). Experiments were performed at least three times. The experiment was performed according to the manufacture's instructions. The minimum detectable concentration was $5 \mathrm{pg} / \mathrm{mL}$ for estradiol and $0.2 \mathrm{ng} / \mathrm{mL}$ for progesterone. For each radioimmunoassay, the intra- and interassay coefficients of variation were less than $10 \%$ and $15 \%$, respectively.

\section{Western blot}

Granulosa cells were lysed with RIPA buffer $(50 \mathrm{mM}$ Tris- $\mathrm{HCl} \mathrm{pH} 7.4,150 \mathrm{mM} \mathrm{NaCl}, 1 \%$ TritonX-100, 1\% sodium deoxycholate, $0.1 \%$ SDS) containing $1 \mathrm{mM}$ phenylmethanesulfonyl fluoride (PMSF). The protein concentration of each group was determined by using the BCA assay reagent (Vigorous Biotechnology, Beijing, China) according to the manufacturer's recommendations. Equal amounts of protein $(50 \mu \mathrm{g})$ were electrophoresed on an $11 \%$ sodium dodecyl sulfate-polyacrylamide gel (SDSPAGE), and the proteins were transferred to polyvinylidene difluoride (PVDF) membrane (Bio-Rad Laboratories). The membrane was blocked with $5 \%(\mathrm{w} / \mathrm{v})$ nonfat dry milk in $0.05 \mathrm{M}, \mathrm{pH} 7.4$ tris-buffered saline (TBS) for $3 \mathrm{~h}$ and incubated with the KRAS antibody $(1: 1000$, abs115469, absin, Shanghai, China) and an internal control GAPDH antibody (1:10000, AM4300, Ambion) overnight at $4^{\circ} \mathrm{C}$. For 3B-HSD, CYP19A1 and 17B-HSD analysis, the membranes were blocked as above and then incubated in diluted primary antibodies overnight at $4^{\circ} \mathrm{C}$. The 3B-HSD antibody was from Santa Cruz (1:500, sc-30821, Santa Cruz, USA), the CYP19A1 (1:200, BA3704, BOSTER,
China) and 17B-HSD (1:200, BA4378-2, BOSTER, China) antibodies were from Boster Biological Technology. And since $17 \mathrm{~B}-\mathrm{HSD}$ antibody is $35 \mathrm{KDa}$, its size is close to the GAPDH, the internal control was replaced with TUBLIN antibody (1:500, 6G7, Developmental Studies Hybridoma Bank). The PVDF membrane was then washed three times for $30 \mathrm{~min}$ in TBST (0.1\% Tween-20 in TBS) and incubated for $2 \mathrm{~h}$ with horseradish peroxidase-conjugated goat antirabbit IgG. After washing for $30 \mathrm{~min}$ with 3 changes of TBST, the membrane was treated with the pierce ${ }^{\mathrm{TM}} \mathrm{ECL}$ 2 Western blot substrate (Thermo scientific). The relative intensity of each blot was assessed and analyzed with the AlphaImager 2200 software package. The intensity values pertaining to each group were normalized against the optical density of GAPDH corresponding to the same group within a single gel and expressed in terms of the means \pm s.E.M. of 3 independent experiments.

\section{Human embryonic kidney 293T cells culture and Luciferase reporter assay}

The human embryonic kidney 293T cell line (293T) was grown in Dulbecco's modified Eagle's medium (DMEM; GIBCO) containing 10\% (V/V) FBS (GIBCO, Grand Island, NY, USA) and $1 \%$ penicillin streptomycin. The cells were also incubated at $37^{\circ} \mathrm{C}$ in a humidified atmosphere of $5 \% \mathrm{CO}_{2}$.

The dual-luciferase reporter genes were constructed using the psiCHECKTM-2 vector (Promega) and the $3^{\prime}$-UTR sequences of mouse CREB5 and KRAS. The KRAS 3'-UTR fragment cloning was done using overlap PCR (Table 2), and Renilla luciferase 3UTR was introduced between the NotI and XhoI sites. The firefly luciferase vector was used for internal reference. The 293T cells were transfected using Lipofectamine2000 with a mixture containing $200 \mathrm{ng} / \mathrm{ml}$ of the dual-luciferase reporter plasmid and $40 \mathrm{nM}$ miR-143 mimics. Cells were transfected with the mut-KRAS vector, serving as a control for normalization. Luciferase activity was measured by a Modulus TMII microplate multimode

Table 2 The CREB5/KRAS-3'UTR sequences containing the miR-143 binding site were constructed into a psi-CHECK 2 vector.

CREB5-3'UTR tcgtgtttcacaaataataggggctaatgtttctcactagcagtctgggcatatgctggtgtttcatctctgcccaaataattcacctcctaacctatgtgtgtgtgtgtgcacatggatgtgtgtgcctgagtgtgtgagtgtgtgtgtgtgtgtgtgt

Mut-CREB5-3'UTR tcgtgtttcacaaataataggggctaatgtttctcactagcagtctgggcatatgctgtcttggtcaacatgcccaaataattcacctcctaacctatgtgtgtgtgtgtgcacatggatgtgtgtgcctgagtgtgtgagtgtgtgtgtgtgtgtgtgt

KRAS-3'UTR aaatatcactggactatgaggactggatgtctgtctgattttaagcaaatcactgtctgcttggttttgaatcatctcaaagacattaacctcccagccgtgtaacatagtttacatgttgacacacctagttatcaagctcagcacaatctgtaactgttttacatggattaacatctt

Mut-KRAS-3'UTR aaatatcactggactatgaggactggatgtctgtctgattttaagcaaatcactgtctgcttggttttgaacggcatgcaagacattaacctcccagccgtgtaacatagtttacatgttgacacacctagttatcaagctcagcacaatctgtaactgt tttacatgga ttaacatctt

http://joe.endocrinology-journals.org DOI: $10.1530 / \mathrm{JOE}-16-0488$ (c) 2017 Society for Endocrinology Printed in Great Britain
Published by Bioscientifica Ltd 
reader (Promega), $24 \mathrm{~h}$ post transfection using a DualLucy Assay Kit (Vigorous Biotechnology Beijing Co., Ltd, China). All transfections were repeated independently at least three times.

\section{Statistical analysis}

All experiments were independently performed three times with different cell preparations in each experiment. Qualitative data reported are representative results obtained from the replicate experiments and presented as mean \pm S.E.M.. Statistical analysis was performed using SPSS 10.0 (SPSS, Inc.). The $t$-test was used to compare the treatment and control samples, and oneway analysis of variance (ANOVA) was used when more than two groups were compared. When differences were observed using ANOVA, pairwise comparisons were made using the $t$-test. A $P$ value $<0.05$ was considered to be statistically significant.

\section{Results}

\section{MiR-143 expression in the mouse ovary}

In order to identify the functions of miR-143 in the mouse ovary, we initially examined miR-143 expression in the mouse ovary by real-time PCR and ISH. The real-time PCR results showed that miR-143 was expressed at very low levels from E11.5 to E15.5, after which ovarian miR-143 expression levels sharply increased and persisted until the adult mouse (Fig. 1A). We further examined the expression of miR-143 in granulosa cells and oocytes by using realtime PCR, and the result revealed that the expression levels of miR-143 in granulosa cells are significantly higher than those in oocytes $(P<0.01)$ (Fig. 1B).
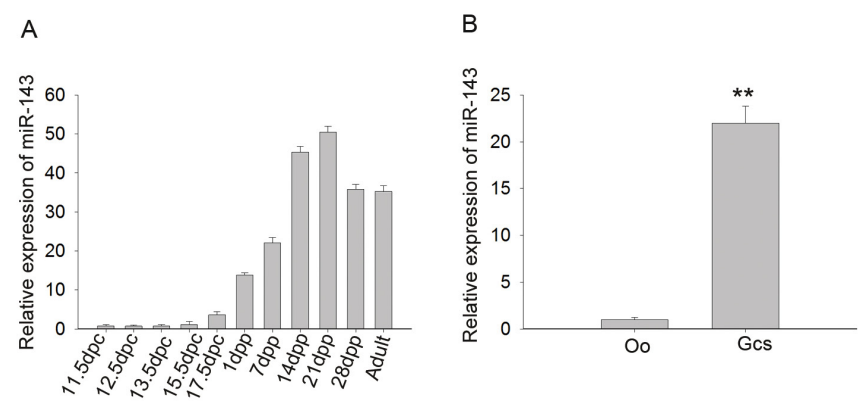

We then localized miR-143 expression in the adult ovary by using a digoxingenin-labeled LNA probe (a scrambled probe was used as a negative control), and the results showed that the miR-143 ISH signal was localized to granulosa cells of primary, secondary and antral follicles (Fig. 1C).

\section{MiR-143 regulates estradiol production}

Since the main function of granulosa cells is to secrete estradiol and progesterone, which modulate the structure and function of female reproductive tissues, we hypothesized that miR-143 is involved in regulating estradiol and progesterone production. To confirm this deduction, the miR-143 in the cultured granulosa cells was, respectively, overexpressed and knocked down by transfecting the miR-143 inhibitor and mimics. The results showed that the miR-143 inhibitor downregulated miR- 143 by $78.6 \%$, while the mimics upregulated miR-143 expression 56-fold (Fig. 2A). Meanwhile, we assessed the effects of the miR-143 inhibitor and mimics on estradiol production in the cultured granulosa cells, and the results revealed that miR-143 mimics decreased estradiol level by $15 \%$. In contrast, the miR-143 inhibitor considerably increased estradiol release by 30\% $(P<0.05)$ (Fig. 2B). It was out of our expectation that neither the miR-143 inhibitor nor the mimics would have a significant effect on progesterone secretion $(P>0.05)$ (Fig. 2C).

We further analyzed the effect of the miR-143 inhibitor and mimics on the expression of genes related to the estradiol synthesis, including STAR, P450scc, 3B$H S D, C Y P 19 A 1$ and 17B-HSD1 in isolated granulosa cells. The results show that the miR-143 inhibitor upregulated 3B-HSD, CYP19A1 and 17B-HSD1 expressions not only at mRNA level but also at protein level. (Fig. 2D, F, G, H,

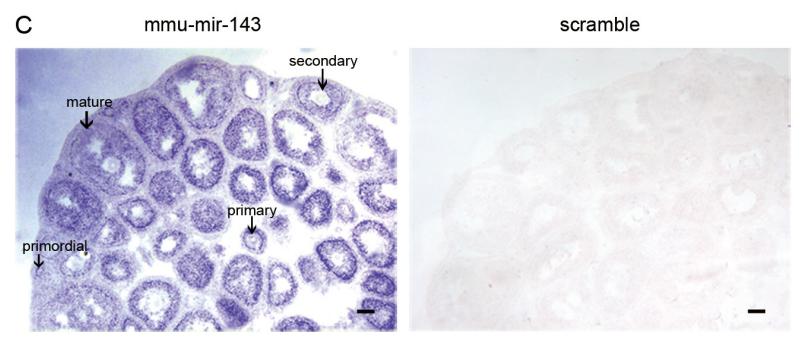

\section{Figure 1}

MiR-143 expression in the mouse ovary. (A) Real-time PCR analysis of miR-143 in the developing mouse ovary. (B) Relative miR-143 expression levels in isolated granulosa cells and oocytes by real-time PCR. GCs, granulosa cells; Oo, oocyte. Data are shown as mean \pm S.E.M. of 3 samples for each group. (C) Localization of miR-143 in mouse ovary using LNA in situ hybridization. Primordial, primary, secondary and mature represent staged follicle. All the scale bars represent $100 \mu \mathrm{m}(* * P<0.01)$.

http://joe.endocrinology-journals.org DOI: $10.1530 / \mathrm{JOE}-16-0488$
๑ 2017 Society for Endocrinology Printed in Great Britain
Published by Bioscientifica Ltd. 

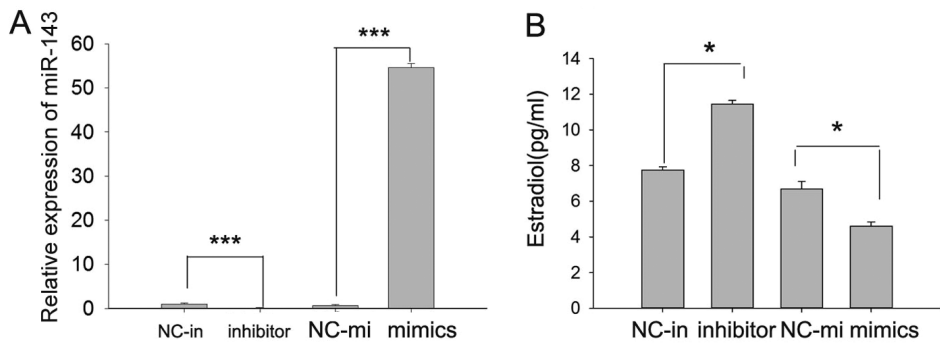

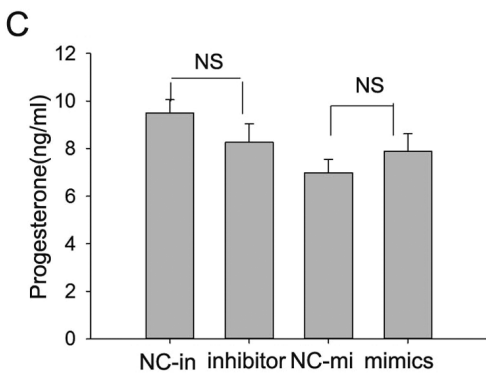

D

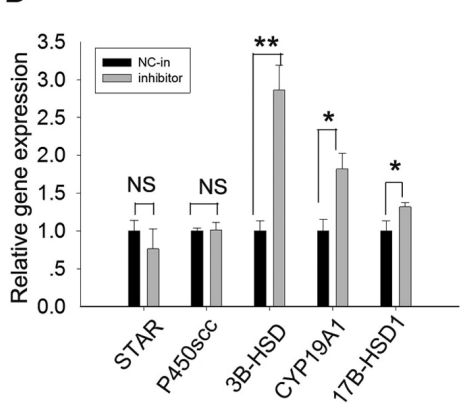

F
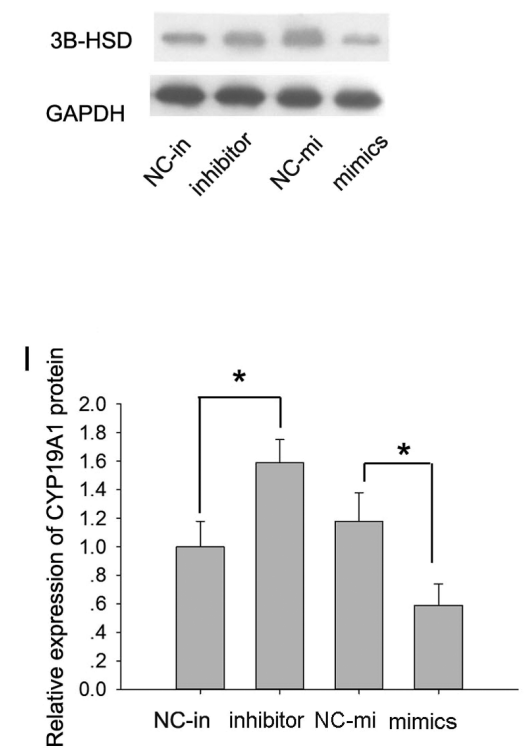

$\mathrm{G}$ 둥

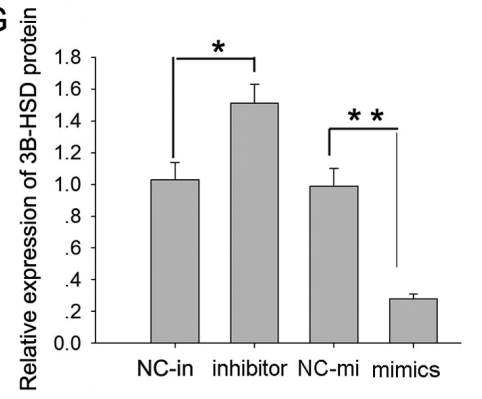

J

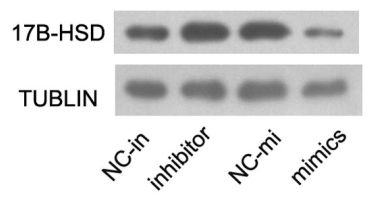

E

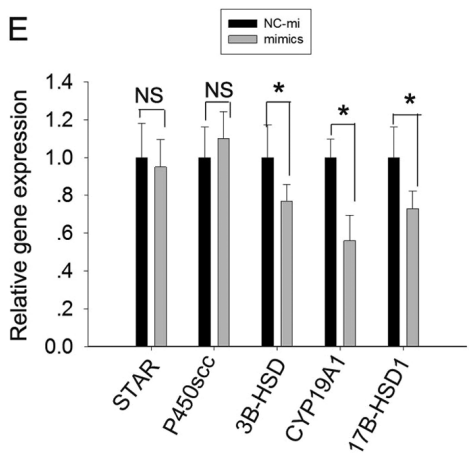

H

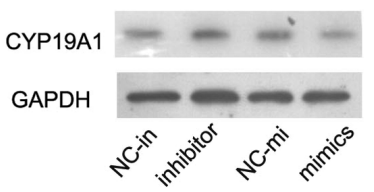

$\mathrm{K}$

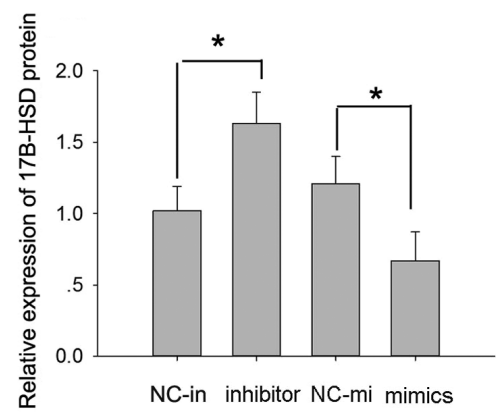

Figure 2

MiR-143 regulates estradiol and steroidogenesis-related genes expression. Periovulatory granulosa cells from large follicles stimulating by PMSG were cultured. (A) Overexpression and inhibition efficiency of miR-143 mimics or inhibitor, transfected into granulosa cells after $24 \mathrm{~h}$. NC-in/NC-mi, miRNA inhibitor/mimics nonsense control, inhibitor: miR-143 inhibitor; mimics: miR-143 mimics. Results are mean \pm S.E.M. of 3 independent experiments, $* * * P<0.001$ (t-test). (B) and (C) Granulosa cells were transfected with miR-143 mimics and mimics control, or miR-143 inhibitor and inhibitor control. The culture media were collected for measuring estradiol and progesterone levels at $24 \mathrm{~h}$ after transfection. Results are mean \pm S.E.M. of 4 independent experiments, $* * * P<0.001$ ( $t$-test). (D) and (E) mRNA levels of steroidogenesis-related enzymes expression in the granulosa cells were measured by real-time PCR after being transfected with an inhibitor and mimics for $24 \mathrm{~h}$. Results are mean \pm S.E.M. of 3 independent experiments done in triplicate and normalized to their respective control ( ${ }^{*} P<0.05 ; * * P<0.01$ and $* * * P<0.001$, by ANOVA. NS, not statistically significant). (F) Analysis of the 3B-HSD protein. Granulosa cells were transfected for $24 \mathrm{~h}$ and protein extracts were analyzed by Western blotting. (G) Quantification of 3B-HSD protein levels. Results are mean \pm S.E.M. of 4 independent experiments; $\left({ }^{*} P<0.05\right.$, by $t$-test). Granulosa cells transfected with miR-143 mimics and mimics control, or miR-143 inhibitor and inhibitor control for $24 \mathrm{~h}$. (H) Western blotting analysis of CYP19A1 in granulosa cells transfected with miR-143 mimics and mimics control, or miR-143 inhibitor and inhibitor control for $24 \mathrm{~h}$. (I) Quantification of CYP19A1 protein levels. Results are mean \pm S.E.M. of 3 independent experiments; $\left({ }^{*} P<0.05\right.$, by $t$-test). (J) Western blotting analysis of 17B-HSD in granulosa cells transfected with miR-143 mimics and mimics control, or miR-143 inhibitor and inhibitor control for 24 h. (K) Quantification of 17B-HSD protein levels. Results are mean \pm S.E.M. of 4 independent experiments; ( ${ }^{*} P<0.05$, by $t$-test). 
I and J), and conversely, the miR-143 mimic decreased 3B-HSD, CYP19A1 and 17B-HSD1 mRNA and protein levels $(P<0.05, P<0.01)$ (Fig. 2E, F, G, H, I and J). However, miR-143 has no effect on STAR and P450scc expressions $(P>0.05)$ (Fig $2 \mathrm{D}$ and $\mathrm{E}$ ). These data demonstrated that miR-143 negatively regulated steroidogenesis-related gene and protein expression.

\section{FSH decreased miR-143 expression in vivo and in cultured granulosa cells in vitro}

It is known that FSH is one of the most important hormones that regulate the ovary's functions, including steroidogenesis. We thus hypothesized that FSH induces steroidogenesis by affecting miR-143 expression. To confirm this assumption, we assayed the ovary's miR-143 expression. There was no significant change except that the miR-143 level was significantly lower at estrous stage (Fig. 3A). However, 10U
(Wei et al. 2015) of PMSG decreased miR-143 levels after $48 \mathrm{~h}$ treatment (Fig. 3B).

Furthermore, the separated mouse granulosa cells were cultured in DMEM/F12 medium with the addition of $100 \mathrm{ng} / \mathrm{ml} \mathrm{FSH}$ (Wayne et al. 2007). MiR-143 levels were assayed after 0 (control) $6 \mathrm{~h}, 12 \mathrm{~h}$ and $24 \mathrm{~h}$ of FSH treatment, and the effect of FSH on miR-143 expression was measured. The FSH treatment decreased miR-143 levels about $83 \%, 70 \%$ and $88 \%$, respectively (Fig. 3C). We then treated the cultured granulosa cells with $0,1,10$ and $100 \mathrm{ng} / \mathrm{ml} \mathrm{FSH}$ for $6 \mathrm{~h}$ and assayed the miR-143 levels. The results showed that 10 and $100 \mathrm{ng} / \mathrm{ml}$ FSH significantly decreased miR-143 expressions $(P<0.05, P<0.01)$, but $1 \mathrm{ng} / \mathrm{ml} \mathrm{FSH}$ had no obvious effects on miR-143 expression (Fig. 3D). These data revealed that the inhibiting effect of FSH on miR-143 expression was closely related to the FSH dose and treatment time.

Since FSH influences CYP19A1 expression and estradiol secretion through different signal pathways,
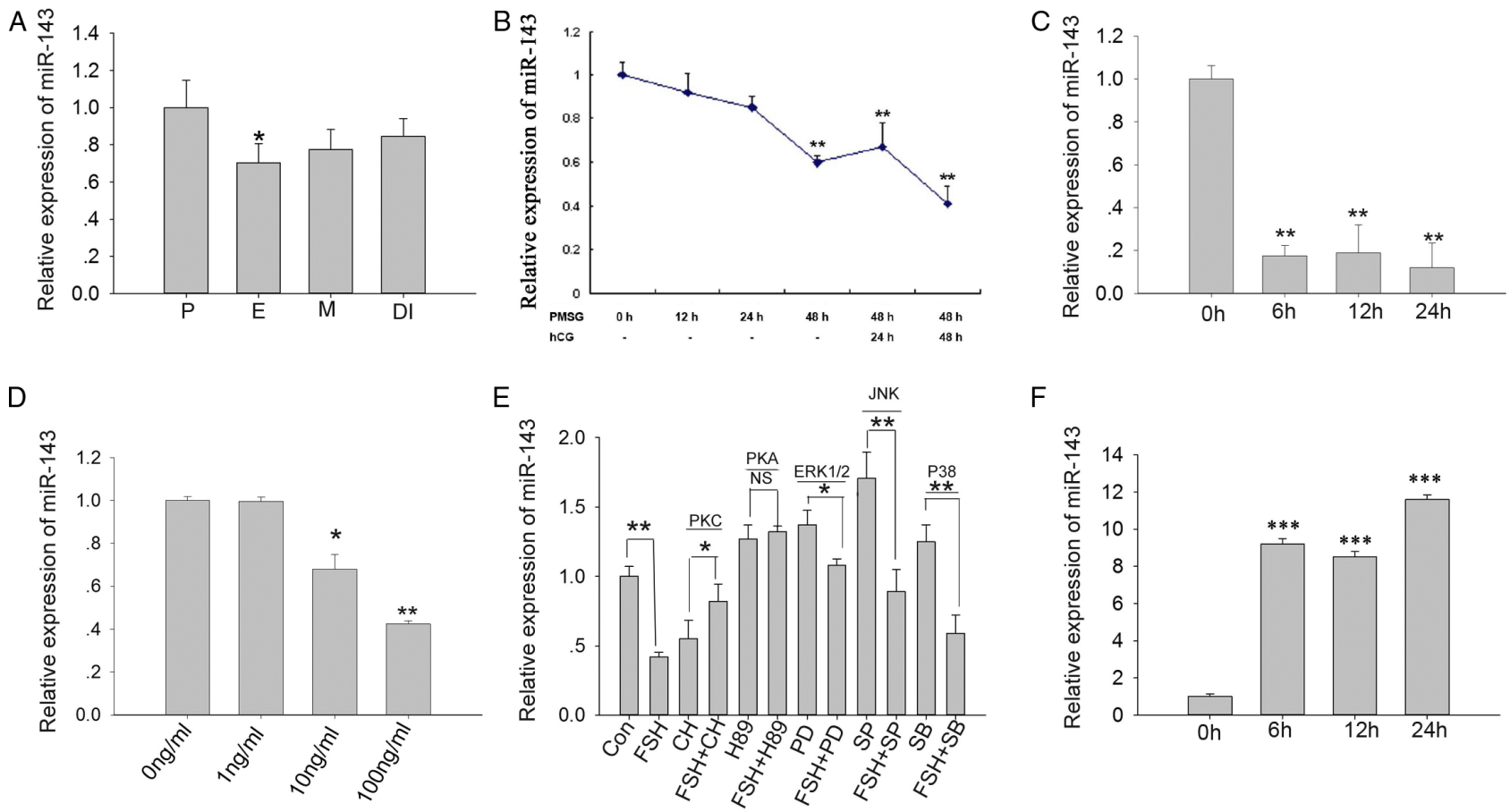

\section{Figure 3}

FSH decreased miR-143 expression in vivo and in vitro. In vitro, Periovulatory granulosa cells from large follicles stimulating by PMSG were cultured. (A) Expression of miR-143 in estrous cycle ovaries by real-time PCR and normalized to the U6 transcript level. P, proestrus stage; E, estrous stage; $\mathrm{M}$, metestrus; DI, diestrus. (B) Expression levels of miR-143 in the ovary from 0 to $48 \mathrm{~h}$ after injection of PMSG and HCG. Results are mean \pm S.E.M. of 3 independent experiments, $* * P<0.01$ (t-test). (C) miR-143 levels at 0 (control), 6, 12, and $24 \mathrm{~h}$ after incubating the granulosa cells with $100 \mathrm{ng} / \mathrm{ml} \mathrm{FSH}$. Results are mean \pm S.E.M. of 4 independent experiments, $* * P<0.01$ ( $t$-test). (D) Expression levels of miR-143 were measured by real-time PCR after incubating the granulosa cells with 0 (control), 1,10 and $100 \mathrm{ng} / \mathrm{mL} \mathrm{FSH} \mathrm{for} 6 \mathrm{~h}$. Results are mean \pm S.E.M. of 4 independent experiments, $* * P<0.01$ (t-test). (E) After several signal pathway inhibitors including $20 \mu \mathrm{M}$ of CH(PKC), H89 (PKA), PD98059 (ERK), SB203580 (p38 MAPK), and SP600125 (JNK) (final concentration $20 \mu \mathrm{M}$ ) and $100 \mathrm{ng} / \mathrm{mL}$ FSH treatment for $24 \mathrm{~h}$, intracellular miR-143 levels in the granulosa cells were assayed by real-time PCR. Data are as shown as mean \pm S.E.M. $(n=3)$. Significance differences are indicated by $* P<0.05, * * P<0.01, * * * P<0.001$ and NS means not significant (by $t$-test). (F) MRNA levels of miR-143 at 0 (control), 6,12 , and $24 \mathrm{~h}$ after incubating the granulosa cells with $1 \mathrm{U} / \mathrm{ml} \mathrm{LH}$. Results are mean \pm S.E.M. of 3 independent experiments done in triplicate and normalized to their respective control $\left({ }^{*} P<0.05 ; * * P<0.01\right.$ and $* * * P<0.001$ by $t$-test).

http://joe.endocrinology-journals.org DOI: $10.1530 / \mathrm{JOE}-16-0488$
๑) 2017 Society for Endocrinology Printed in Great Britain
Published by Bioscientifica Ltd 
such as PKA, PKC, ERK1/2 and P38 (Meroni et al. 2004, Hunzicker-Dunn et al. 2012, Fa et al. 2013, Chen et al. 2014), we determined to find out the signaling pathway in which miR-143 is regulated by FSH. Cultured granulosa cells were separately pretreated with $\mathrm{CH}$ (a PKC inhibitor), H89 (a PKA inhibitor), PD98059 (an ERK1/2 inhibitor), SP600125 (a JNK inhibitor) and SB203580 (a P38 inhibitor) for $1 \mathrm{~h}$, and then treated with $100 \mathrm{ng} / \mathrm{ml} \mathrm{FSH}$ for $6 \mathrm{~h}$. MiR143 expression was then assayed by real-time PCR. The results showed that miR-143 expression was rescued by $\mathrm{H} 89$ and $\mathrm{CH}$ treatments. However, the other inhibitors had no effects on miR-143 expression. This suggested that FSH decreased miR-143 expression through the PKA or PKC pathways (Fig. 3E).

The expression level of miR-143 after incubating mouse granulosa cells with $\mathrm{LH}(1 \mathrm{U} / \mathrm{ml})$ for $0,6,12$ and $24 \mathrm{~h}$ was examined by real-time PCR, and the results revealed that $\mathrm{LH}$ had an enhancing effect on miR-143 expression after the cells were cultured for 6,12 and $24 \mathrm{~h}$ (Fig. 3F). These data revealed that LH upregulated the expression of miR-143.

\section{MiR-143 mediates the FSH signaling pathway influencing estradiol production}

FSH is a key factor influencing estradiol production. To confirm that miR-143 is involved in the FSH signaling pathway, cultured granulosa cells were transfected with miR-143 mimics and miR-143 inhibitor for $24 \mathrm{~h}$ and then treated with $100 \mathrm{ng} / \mathrm{ml} \mathrm{FSH}$ for $12 \mathrm{~h}$. CYP19A1 expression and estradiol levels were then measured. The results showed that miR-143 inhibitor increased both basal and FSH-enhanced estradiol production and CYP19A1 expression (Fig. 4A and C). We also found that as expected, FSH increased estradiol secretion and upregulated CYP19A1 expression in cells transfected with negative control mimics, but this effect vanished in cells that overexpressed miR-143 (Fig. 4B and D). These results demonstrated that miR143 negatively regulated FSH's stimulatory action on estradiol production.

\section{MiR-143 is involved in granulosa cell proliferation}

Estradiol levels generally change through two pathways, one is the cell state, such as the status of enzymes important for the synthesis of estradiol, another is through a change in the number of cells that secrete estradiol. The above experiments have verified the effects of miR-143 on the expression of estradiol synthesis-related genes. To explore the effects of miR-143 on granulosa cell proliferation, BrdU staining was carried out after transfection of miR-143 mimics or miR-143 inhibitor for $24 \mathrm{~h}$ or $48 \mathrm{~h}$ (Supplementary Fig. 2). We counted BrdU-positive cells in more than 5000 cells per treatment. There was roughly $44 \%$ less BrdU-positive cells in miR-143 mimics than in the control group $(P<0.05)$. MiR-143 silencing significantly increased the number of cells compared to the controls $(P<0.01)$ (Fig. 5A and B).

Furthermore, we analyzed the effect of miR-143 on the expression of genes related to the cell cycle, including Cyclin B1, D2, E2 and Cdk 4 and 6 in isolated granulosa cells after transfection with the miR-143 inhibitor and mimics. The results showed that the miR-143 inhibitor increased Cyclin B1, D2, E2 and Cdk4, 6 mRNA levels $(P<0.01$, $P<0.001$ ) (Fig. 5C), and conversely, miR-143 mimics decreased Cyclin B1, D2, E2 and Cdk4, 6 mRNA levels $(P<0.05, P<0.01)$ (Fig. 5D). These data demonstrated that miR-143 negatively regulated the proliferation of granulosa cells.
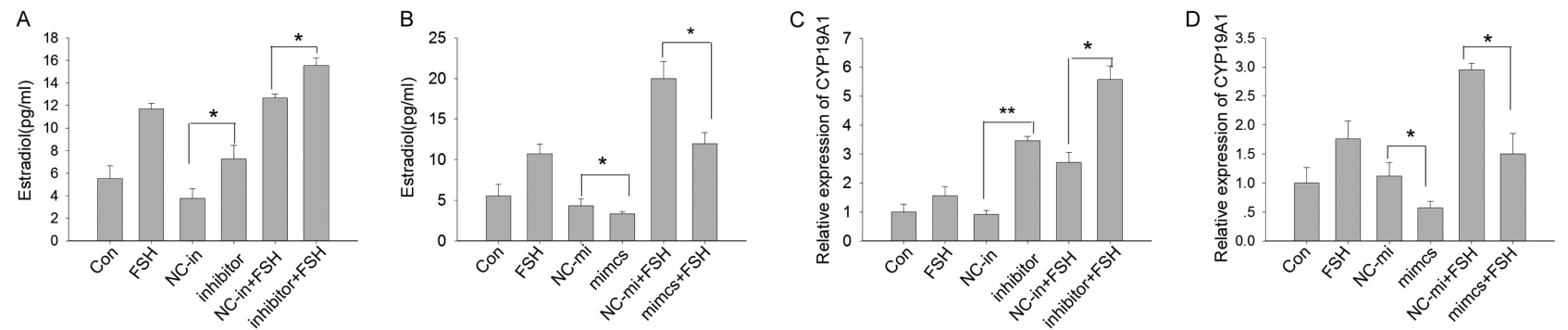

Figure 4

MiR-143 is involved in the FSH signaling pathway. Periovulatory granulosa cells from large follicles stimulating by PMSG were cultured. (A) and (B) Estradiol secreted by granulosa cells. The cells were transfected with either miR-143 inhibitors or miR-143 mimics. Twenty-four hours later, the cells were treated with FSH $(100 \mathrm{ng} / \mathrm{mL})$ for $12 \mathrm{~h}$. Results are mean \pm S.E.M. of 4 independent experiments, ${ }^{*} P<0.05$ ( $t$-test). (C) and (D) mRNA levels of $C Y P 19 A 1$. Results are mean \pm S.E.M. of 4 independent experiments done in triplicate and normalized to their respective control. $\left({ }^{*} P<0.05 ; * * P<0.01\right.$ by ANOVA). 
A

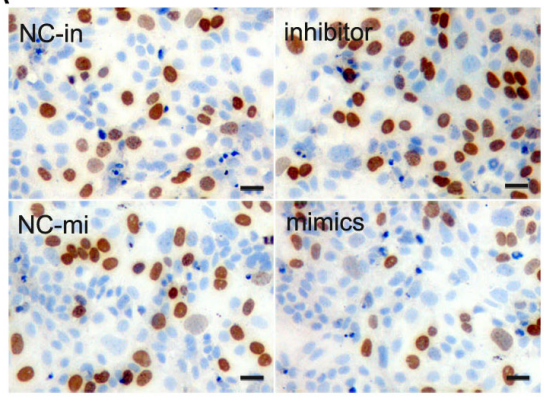

C

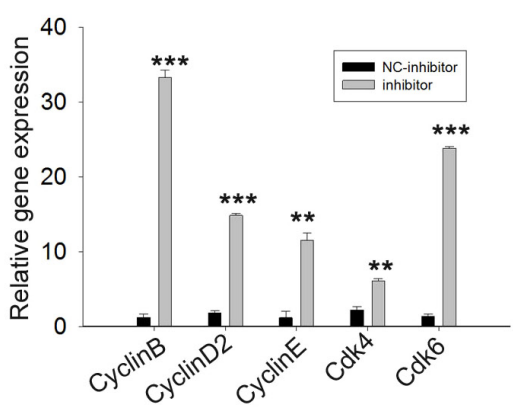

B

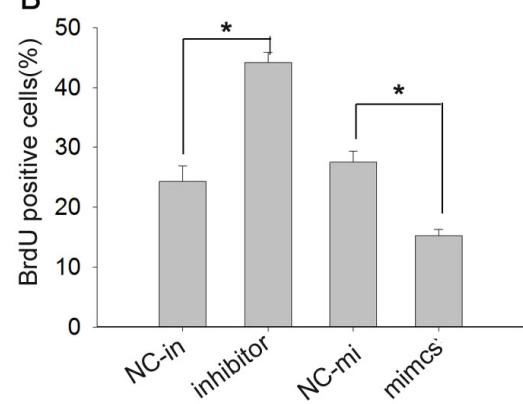

D

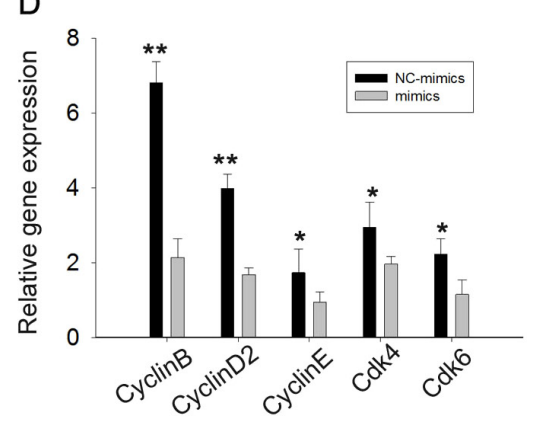

Figure 5

Effects of miR-143 on granulosa cell proliferation. Periovulatory granulosa cells from large follicles stimulating by PMSG were cultured then transfected with miR-143 mimics or inhibitors for 24h. (A) Granulosa cell proliferation was measured by using BrdU analysis. All the scale bars represent $100 \mu \mathrm{m}$. (B) Percentages of BrdU-positive cells accounting for the total granulosa cells. (C) and (D) mRNA levels of cell cycle-related genes were measured by real-time PCR. NC-in or NC-mi were used as inhibitor or mimics controls. Results are mean \pm S.E.M. of 3 independent experiments done in triplicate and normalized to their respective control ( ${ }^{*} P<0.05$, ${ }^{* *} P<0.01$ and $* * * P<0.001$ by $t$-test).

\section{KRAS is a direct target of miR-143}

To determine the potential target of miR-143 affecting estradiol synthesis and granulosa cells proliferation in mouse granulosa cells, we used computational prediction algorithms, including miRanda and pictar. Among the putative target genes, KRAS plays important role in cell proliferation and CREB5 responses to the PKA signaling. In addition, previous reports have showed that KRAS is a target of miR-143 in other organs (Chen et al. 2009, $\mathrm{Xu}$ et al. 2011b, Wu et al. 2013). We predicted that CREB5 and KRAS were candidates of miR-143 targeting genes (Fig. 6A). The 3 UTR of CREB5 and KRAS mRNA were then inserted downstream from the Renilla luciferase coding region in the reporter vector (Table 2, Fig. 6B and C). A 3 UTR of CREB5 mRNA with eight mutated nucleic acids and a 3'UTR of KRAS mRNA with six mutated nucleic acids in the seed sequence were used as negative controls (Table 2, Fig. 6B). Each reporter construct was separately co-transfected into $293 \mathrm{~T}$ cells with the miR-143 mimicking molecules. Compared to the mut-KRAS-3UTR control, the luciferase activity declined by about $40 \%$ after the transfection with miR-143 mimics and the KRAS-3UTR reporter vector (Fig. 6E). However, there was no difference between the NC-mimics and the miR-143 mimics group after transfecting the cells with the CREB5-3'UTR reporter vector (Fig. 6D). Further functional analysis indicated that miR-143 overexpression in granulosa cells resulted in a reduction of KRAS protein levels, whereas the inhibition of miR-143 significantly increased the KRAS protein levels (Fig. 6G and $\mathrm{H}$ ) without affecting KRAS mRNA levels (Fig. 6F). These results indicated that KRAS is the direct target gene of miR-143.

\section{KRAS is involved in the signaling pathway of FSH that regulates estradiol production}

To identify whether KRAS is involved in the signaling pathway of FSH that regulates estradiol production, cultured granulosa cells were treated with $0 \mathrm{ng} / \mathrm{mL}$, $1 \mathrm{ng} / \mathrm{mL}, 10 \mathrm{ng} / \mathrm{mL}$ and $100 \mathrm{ng} / \mathrm{mL}$ FSH for $6 \mathrm{~h}$, and KRAS expression was assayed. The results showed that FSH sharply increased KRAS mRNA levels at $10 \mathrm{ng} / \mathrm{mL}$ and $100 \mathrm{ng} / \mathrm{mL}$, and there was no obvious influence at $1 \mathrm{ng} / \mathrm{mL}$ (Fig. 7A). Western blot analysis also showed that FSH significantly upregulated KRAS protein levels at $10 \mathrm{ng} / \mathrm{mL}$ and $100 \mathrm{ng} / \mathrm{mL}$ (Fig. $7 \mathrm{~B}$ and C). However, in the presence of miR-143 mimics, FSH fails to increase KRAS expression (Fig. D and E). We then constructed three kinds of KRAS siRNA and chose the KRAS siRNA1 which had the highest inhibition on KRAS mRNA (Fig. 7F). KRAS siRNA1 partly inhibited the effect of FSH on estradiol levels by 45\% (Fig. 7G). These preliminary results demonstrated that KRAS plays an important role in mediating the regulatory effect of FSH on estradiol production. 
A
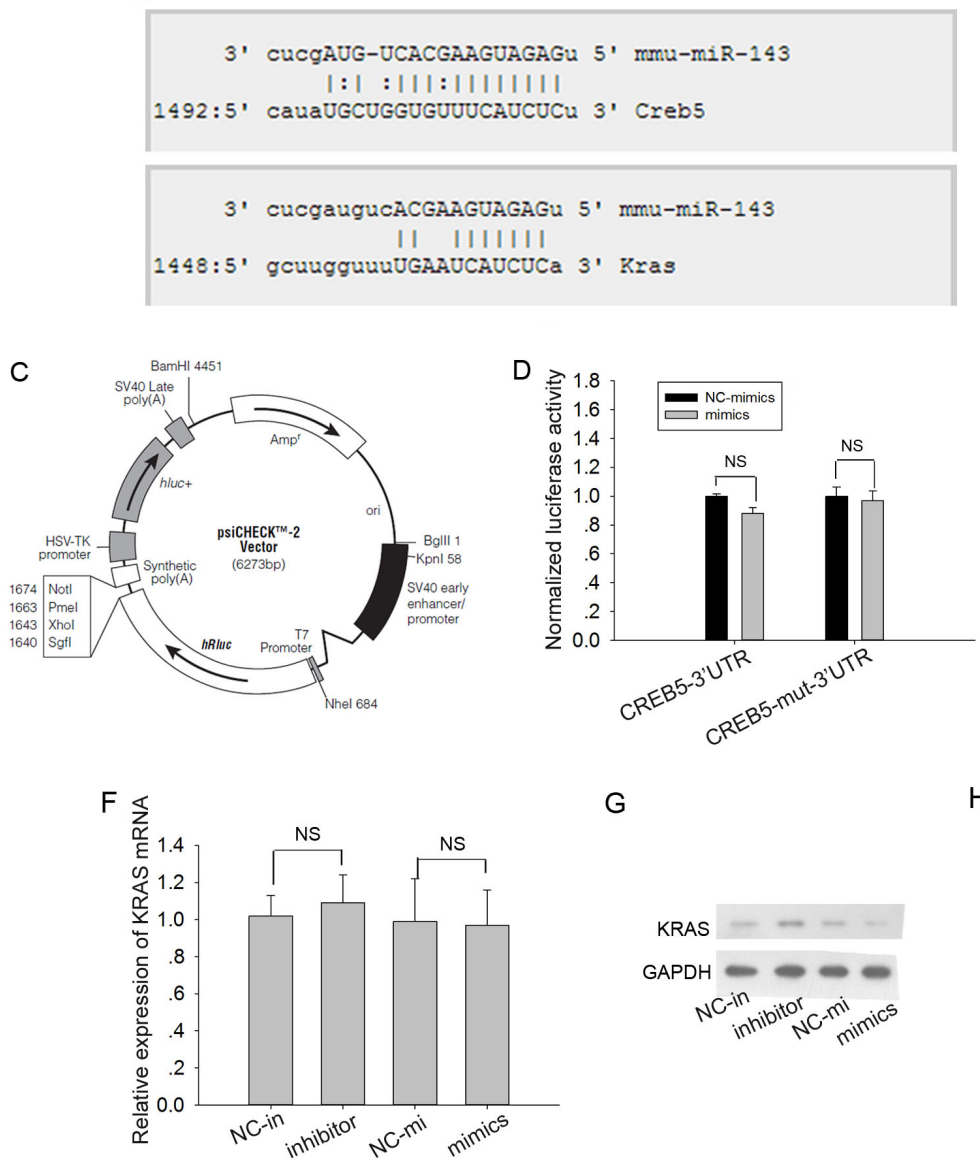

B
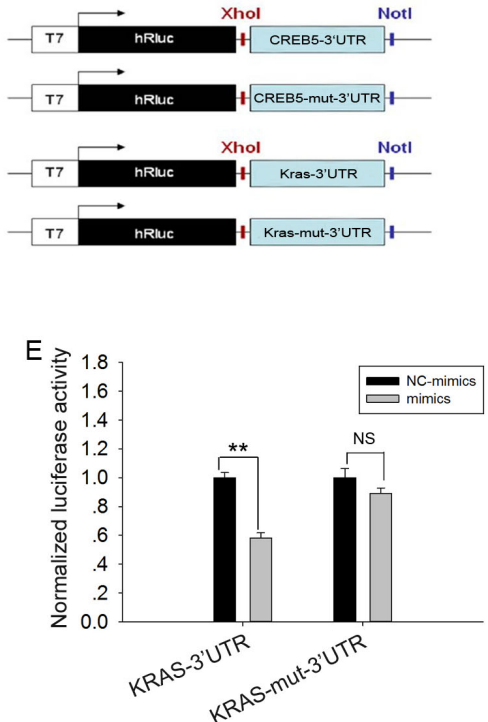

$\mathrm{H}$

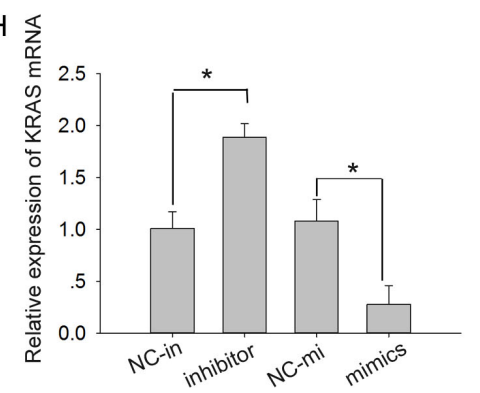

Figure 6

MiR-143 binds to KRAS-3'UTR, which regulates its protein expression. (A) The predicted miR-143 binding site in CREB5-3'UTR and KRAS-3'UTR from www.miRNA.org. (B) Schematic of inserted CREB5-3'UTR and KRAS-3'UTRs sequences. (C) The psi-CHECKTM-2 reporter vector map. (D) and (E) Relative luminescence intensity detected by the Modulus TMII microplate multimode reader after miR-143 mimics and dual-luciferase vector were co-transfected into $293 \mathrm{~T}$ cells for $24 \mathrm{~h}$. Results are means \pm S.E.M. of three independent experiments done in triplicate and normalized to their respective control. $(* * P<0.01$. NS, not statistically significant). (F) Quantification of KRAS mRNA levels. Periovulatory granulosa cells from large follicles stimulating by PMSG were cultured. Granulosa cells were transfected with an NC-inhibitor (NC-in), miR-143 inhibitor, NC-mimics (NC-mi), miR-143 mimics for $6 \mathrm{~h}$. The data are mean \pm S.E.M.. for multiple separate transfections $(n=3)$. (NS, not statistically significant by $t$-test). (G) Analysis of the KRAS protein. Granulosa cells were transfected an NC-inhibitor (NC-in), miR-143 inhibitor, NC-mimics (NC-mi), miR-143 mimics for 24h and protein extracts were analyzed by Western blotting. (H) Quantification of KRAS protein levels. Results are mean \pm S.E.M. of three independent experiments $(* P<0.05 ;$ NS, not significant). Data are presented as mean \pm s.E.M. $(n=3)(P<0.05$, by $t$-test $)$.

\section{Discussion}

We detected miR-143 expression in the mouse ovary from $17.5 \mathrm{dpc}$ to $4 \mathrm{dpp}$, the period of primordial follicle formation (Zhang et al. 2013). Previous studies revealed that miR-143 is located in granulosa cells of primary, secondary and antral follicles in the mouse ovary (Yao et al. 2009). However, the functions of miR-143 in the postnatal ovary have not been established. Our results presented here show that miR-143 is located in the granulosa cells of the mouse ovary, which infers that miR-143 plays important role in regulating the follicular development through its effect on granulosa cell proliferation and related ovarian hormone secretion. Furthermore, by using a silencing and overexpression approach, we demonstrate that miR-143 negatively regulates granulosa cell proliferation and mediates FSH-induced estradiol production by targeting KRAS. Our results revealed that miR-143 mimics decreased estradiol level by $15 \%$ and the miR-143 inhibitor considerably increased estradiol release by $30 \%$. While a $15-30 \%$ variation in estradiol levels is a moderate change, as hormones play a role by regulating the amount and activity of regulatory factors and can amplify the regulatory signal, this can lead to significant changes in the body. In addition, the earliest occurrence of any disease is caused by a long-term minimal alteration. 
A

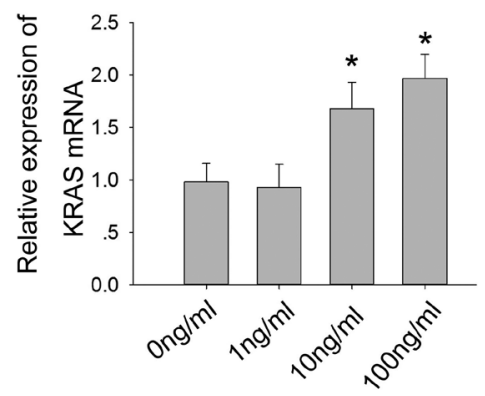

$\mathrm{E}$

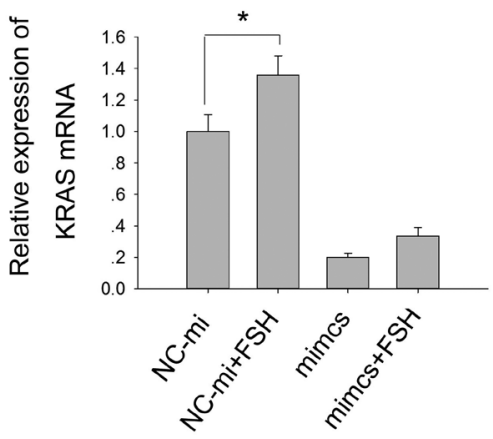

B

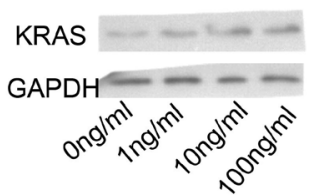

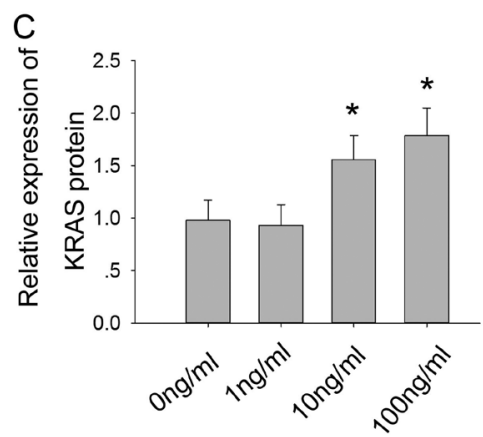

D

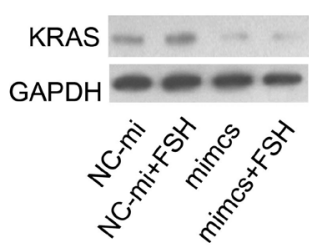

$\mathrm{F}$

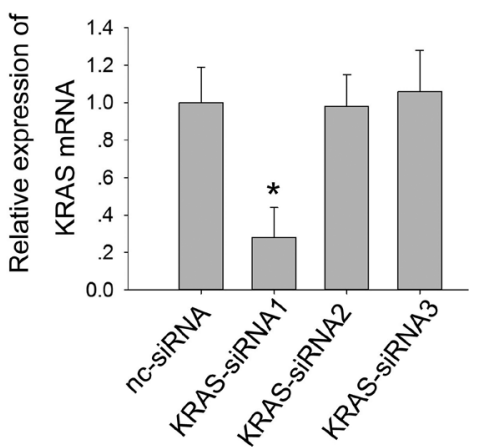

G

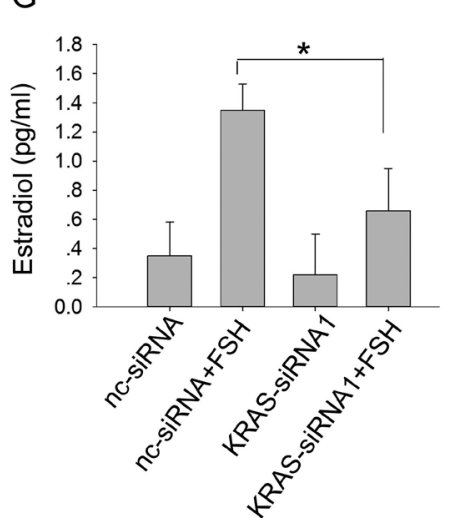

Figure 7

KRAS functions in regulating estradiol stimulated by FSH. Periovulatory granulosa cells from large follicles stimulating by PMSG were cultured. (A) Expression levels of KRAS mRNA were measured by real-time PCR after incubating the GCs with 0 (control), 1, 10 and $100 \mathrm{ng} / \mathrm{mL}$ FSH for $6 \mathrm{~h}$. Data are presented as mean \pm S.E.M.. $(n=4)(* P<0.05$ by $t$-test). (B) KRAS protein expression levels were analyzed by Western blotting after incubating the granulosa cells with 0 (control), 1,10 and $100 \mathrm{ng} / \mathrm{mL} \mathrm{FSH} \mathrm{for} 24 \mathrm{~h}$. (C) Quantification of KRAS protein levels. Data are presented as mean \pm S.E.M. ( $n=3$ ) ( ${ }^{*}<0.05$, by ANOVA). (D) KRAS protein expression levels were analyzed by Western blotting after the granulosa cells transfected with the NC-inhibitor (NC-in), miR-143 inhibitor, NC-mimics (NC-mi), miR-143 mimics for $24 \mathrm{~h}$. (E) Quantification of KRAS protein levels. Data are presented as mean \pm S.E.M. $(n=3)(* P<0.05$ by ANOVA). (F) Quantification of intracellular KRAS mRNA levels after the granulosa cells were transfected with KRAS siRNA1-3 for $24 \mathrm{~h}$. Data are presented as mean \pm S.E.M. $(n=3)\left({ }^{*} P<0.05\right.$ by ANOVA). (G) Estradiol levels were detected after transfecting nc siRNA or $K R A S$ siRNA1 and $24 \mathrm{~h}$ later, $100 \mathrm{ng} / \mathrm{ml} \mathrm{FSH}$ was added to granulosa cells and were treated for $12 \mathrm{~h}(n=4)(* P<0.05$ by $t$-test).

For example, polycystic ovary syndrome is triggered by endocrine disorders. Detailed in vivo experiments are required to further investigate the physiological function of miR-143 in the ovary.

MiR-143 expression has been detected in different tissues, such as the ventricular chamber (Deacon et al. 2010) and several types of tumors (Chen et al. 2009, Clape et al. 2009), and functional studies have shown that miR-143 is required for the ventricular chamber formation (Deacon et al. 2010), and tumor cells proliferation (Iorio et al. 2007a). In this study, the expression of miR143 in the developing mouse ovary sharply increased at $17.5 \mathrm{dpc}$, when primordial follicle begins to formation, and persisted until the adult mouse. ISH results showed that miR-143 is expressed in the granulosa cells of primary, secondary and antral follicles, and indicated that miR-143 plays an important role in granulosa cell functions.
FSH has been implicated in regulating granulosa cells proliferation/differentiation and estradiol secretion, which are critical for the structure and function of female reproductive tissues (Pasapera et al. 2005). Previous reports have shown that several miRNAs are under control of FSH in granulosa cells, including miR-143 (Yao et al. 2009). We therefore postulated that miR-143 participates in FSHinduced estradiol production in granulosa cells. RIA and real-time PCR results revealed that the estradiol levels and the mRNA levels of steroidogenic enzymes, including 3B-HSD, CYP19A1, and 17B-HSD1, increased when miR143 was silenced, suggesting that miR-143 acts as a negative regulating molecule in estradiol synthesis and secretion in granulosa cells.

FSH has long been considered as a key regulating factor of estradiol production by the granulosa cells during the development of the dominant follicle 
(Erickson 1983). In the estradiol pathway, FSH induces the expression of P450arom (the CYP19 gene) and the type 1 17B-hydroxysteroid dehydrogenase (17B-HSD), which metabolize theca-derived androstenedione to estradiol (Erickson 1983). In the current study, the expression levels of miR-143 decreased in the estrous stage of the ovarian estrous cycle and injecting the ovary with PMSG, when the FSH levels were high in vivo. Furthermore, FSH decreased miR-143 expression in cultured granulosa cells through the PKA-ERK1/2 signaling pathway in vitro, which subsequently decreased aromatase activity and estradiol production.

In order to assess whether the effect of FSH on estradiol production depends on miR-143, we examined FSH-induced estradiol production with a miR-143 inhibitor or mimics. Our results revealed that the miR-143 inhibitor increases both basal and FSH-enhanced estradiol production and increases the mRNA levels of estradiolgenerating enzymes, including CYP19A1 and 17B-HSD1, suggesting that miR-143 plays a negative regulatory role in FSH-induced estradiol synthesis and production.

It is well documented that miR-143 is an antiproliferation gene in many cancer cells (Chen et al. 2009, Clape et al. 2009). Since follicular development is accompanied by a large proliferation of their surrounding granulosa cells, we thus postulated that miR-143 is involved in the proliferative regulation of granulosa cells. Our results demonstrate that there is a sharp reduction in granulosa cell proliferation and in the expression of the genes that are closely associated with cell proliferation when miR143 was overexpressed, and the reverse happened when we inhibited miR-143. These results demonstrate that miR-143 plays a negative role in regulating granulosa cell proliferation similar to its function in cancer cells. However, further in vivo experiments are required to further elucidate the physiological function of miR-143 in the ovary.

Effective inhibition of mRNA translation by microRNAs is known to be mediated by binding to specific 3UTR sites. KRAS 3UTR has a miR-143 binding sequence. KRAS is a small G-protein that is correlated with colorectal cancer cell proliferation (Fan et al. 2009, Liu et al. 2011), and KRAS is the target gene of miR-143 in colorectal tumorigenesis (Chen et al. 2009). Moreover, KRAS is highly expressed in granulosa cells, which is involved in follicle development and ovulation (Fan et al. 2008). Here, we demonstrated that miR-143 directly binds the KRAS gene. Furthermore, our in vitro experiments have shown that FSH downregulated miR-143 and upregulated
KRAS in granulosa cells. miR-143 repressed the luciferase reporter gene expression by targeting the 3UTR binding site in vitro, indicating a direct interaction site between miR-143 and 3UTR of KRAS.

$K R A S$, an oncogene, is suggested to play a pivotal role in the transduction of several growth or differentiation factor stimuli. It has been reported that the expression levels of KRAS are related to the malignant degree of cancers, including glioma, breast cancer, melanoma and other cancers (Fitzgerald et al. 2015, Ze-An Qiu1 2016). In this study, FSH increased KRAS protein expression through the downregulation of miR-143, and KRAS mediated the roles of miR-143 to influence estradiol production and function. These results not only validate the functional relevance of KRAS (a target gene of miR-143) in FSH/ miR-143-stimulated mouse granulosa cells, but also provide a new molecular mechanism on FSH regulation of KRAS. It was reported that miR-143 decrease prostate cancer cells proliferation and migration and enhances their sensitivity to docetaxel through suppression KRAS (Xu et al. 2011a). In the current study, we demonstrate that miR-143 negatively regulates the proliferation of granulosa cells and its target gene is KRAS. These results indicated that KRAS may be a link between miR143 and proliferation.

In conclusion, we have shown that miR-143 is highly expressed in the mouse ovarian granulosa cells, and it acts as a negative mediator to regulate FSH-induced esradiol production by targeting KRAS. In addition, miR-143 also regulates granulosa cells proliferation. In the light of our study, tissue-specific microRNAs, such as miR-143, can be used as novel targets for physiological or pharmacological interventions in diseases resulting from abnormal ovarian granulosa cell proliferative and hormone secretion.

\section{Supplementary data}

This is linked to the online version of the paper at http://dx.doi.org/10.1530/ JOE-16-0488.

\section{Declaration of interest}

The authors declare that there is no conflict of interest that could be perceived as prejudicing the impartiality of the research reported.

\section{Funding}

This work was supported by the Natural Science Foundation of China (31172288).
() 2017 Society for Endocrinology Printed in Great Britain
Published by Bioscientifica Ltd 


\section{Author contribution statement}

Sheng Cui conceived and designed the experiments; Li Zhang and Xiaoxin Zhang carried out the experiments; Li Zhang, Xuejing Zhang and Xiaoxin Zhang analyzed the data; Xiaoxin Zhang and Lei Li provided the reagents/ materials/analysis tools; and Sheng Cui and Li Zhang wrote the manuscript.

\section{References}

Chen Q, Zhang WQ, Ran H, Feng LZ, Yan H, Mu XY, Han YY, Liu W, Xia GL \& Wang C 2014 PKC delta and theta Possibly Mediate FSHInduced Mouse Oocyte Maturation via NOX-ROS-TACE Cascade Signaling Pathway. PLOS ONE 9 e111423. (doi:10.1371/journal. pone.0111423)

Chen X, Guo X, Zhang H, Xiang Y, Chen J, Yin Y, Cai X, Wang K, Wang G, Ba Y, et al. 2009 Role of miR-143 targeting KRAS in colorectal tumorigenesis. Oncogene 28 1385-1392. (doi:10.1038/onc.2008.474)

Clape C, Fritz V, Henriquet C, Apparailly F, Fernandez PL, Iborra F, Avances C, Villalba M, Culine S \& Fajas L 2009 miR-143 Interferes with ERK5 signaling, and abrogates prostate cancer progression in mice. PLoS ONE 4 e7542. (doi:10.1371/journal.pone.0007542)

Craig J, Orisaka M, Wang H, Orisaka S, Thompson W, Zhu C, Kotsuji F \& Tsang BK 2007 Gonadotropin and intra-ovarian signals regulating follicle development and atresia: the delicate balance between life and death. Frontiers in Bioscience 12 3628-3639. (doi:10.2741/2339)

Deacon DC, Nevis KR, Cashman TJ, Zhou Y, Zhao L, Washko D, GunerAtaman B, Burns CG \& Burns CE 2010 The miR-143-adducin3 pathway is essential for cardiac chamber morphogenesis. Development 137 1887-1896. (doi:10.1242/dev.050526)

Downward J 2003 Targeting RAS signalling pathways in cancer therapy. Nature Reviews Cancer 3 11-22. (doi:10.1038/nrc969)

Erickson GF 1983 Primary cultures of ovarian-cells in serum-free medium as models of hormone-dependent differentiation. Molecular and Cellular Endocrinology 29 21-49. (doi:10.1016/0303-7207(83)90003-5)

Fa S, Pogrmic-Majkic K, Samardzija D, Glisic B, Kaisarevic S, Kovacevic R \& Andric N 2013 Involvement of ERK1/2 signaling pathway in atrazine action on FSH-stimulated LHR and CYP19A1 expression in rat granulosa cells. Toxicology and Applied Pharmacology 270 1-8. (doi:10.1016/j.taap.2013.03.031)

Fan HY, Liu ZL, Paquet M, Wang JR, Lydon JP, DeMayo FJ \& Richards JS 2009 Cell type-specific targeted mutations of Kras and Pten document proliferation arrest in granulosa cells versus oncogenic insult to ovarian surface epithelial cells. Cancer Research 69 6463-6472. (doi:10.1158/0008-5472.CAN-08-3363)

Fan HY, Shimada M, Liu ZL, Cahill N, Noma N \& Richards J 2008 Selective expression of constitutively active KrasG12D in granulosa cells of the mouse ovary causes defects in follicle development and ovulation. Biology of Reproduction 135 2127-2137. (doi:10.1093/ biolreprod/78.s1.127a)

Farazi TA, Juranek SA \& Tuschl T 2008 The growing catalog of small RNAs and their association with distinct Argonaute/Piwi family members. Development 135 1201-1214. (doi:10.1242/dev.005629)

Fiedler SD, Carletti MZ, Hong X \& Christenson LK 2008 Hormonal regulation of MicroRNA expression in periovulatory mouse mural granulosa cells. Biology of Reproduction 79 1030-1037. (doi:10.1095/ biolreprod.108.069690)

Fitzgerald TL, Lertpiriyapong K, Cocco L, Martelli AM, Libra M, Candido S, Montalto G, Cervello M, Steelman L, Abrams SL, et al. 2015 Roles of EGFR and KRAS and their downstream signaling pathways in pancreatic cancer and pancreatic cancer stem cells. Advances in Biological Regulation 59 65-81. (doi:10.1016/j.jbior.2015.06.003)

Frishman GN, Luciano AA \& Peluso JJ 1992 Effect of the ratio of folliclestimulating hormone to luteinizing hormone on rat granulosa cell proliferation and oestradiol-17 beta secretion. Human Reproduction $\mathbf{7}$ 1073-1078. (doi:10.1093/oxfordjournals.humrep.a137795)
Hanoux V, Pairault C, Bakalska M, Habert R \& Livera G 2007 Caspase-2 involvement during ionizing radiation-induced oocyte death in the mouse ovary. Cell Death \& Differentiation 14 671-681. (doi:10.1038/ sj.cdd.4402052)

Hong XM, Luense LJ, McGinnis LK, Nothnick WB \& Christenson LK 2008 Dicer1 Is essential for female fertility and normal development of the female reproductive system. Endocrinology 149 6207-6212. (doi:10.1210/en.2008-0294)

Hunzicker-Dunn ME, Lopez-Biladeau B, Law NC, Fiedler SE, Carr DW \& Maizels ET 2012 PKA and GAB2 play central roles in the FSH signaling pathway to PI3K and AKT in ovarian granulosa cells. PNAS 109 E2979-E2988. (doi:10.1073/pnas.1205661109)

Iorio MV, Visone R, Di Leva G, Donati V, Petrocca F, Casalini P, Taccioli C, Volinia S, Liu CG, Alder H, et al. 2007a MicroRNA signatures in human ovarian cancer. Cancer Research 67 8699-8707. (doi:10.1158/0008-5472.CAN-07-1936)

Iorio MV, Visone R, Di Leva G, Donati V, Petrocca F, Casalini P, Taccioli C, Volinia S, Liu CG, Alder H, et al. 2007b MicroRNA signatures in human ovarian cancer. Cancer Research 67 8699-8707. (doi:10.1158/0008-5472.CAN-07-1936)

Lei L, Jin S, Gonzalez G, Behringer RR \& Woodruff TK 2010 The regulatory role of Dicer in folliculogenesis in mice. Molecular and Cellular Endocrinology 315 63-73. (doi:10.1016/j.mce.2009.09.021)

Liu XL, Jakubowski M \& Hunt JL 2011 KRAS gene mutation in colorectal cancer is correlated with increased proliferation and spontaneous apoptosis. American Journal of Clinical Pathology 135 245-252. (doi:10.1309/AJCP7FO2VAXIVSTP)

Malumbres M \& Barbacid M 2003 RAS oncogenes: the first 30 years. Nature Reviews Cancer 3 459-465. (doi:10.1038/nrc1097)

Mattes J, Yang M \& Foster PS 2007 Regulation of microRNA by antagomirs: A new class of pharmacological antagonists for the specific regulation of gene function? American Journal of Respiratory Cell and Molecular Biology 36 8-12. (doi:10.1165/rcmb.20060227TR)

Meroni SB, Riera MF, Pellizzari EH, Galardo MN \& Cigorraga SB 2004 FSH activates phosphatidylinositol 3-kinase/protein kinase B signaling pathway in 20-day-old Sertoli cells independently of IGF-I. Journal of Endocrinology 180 257-265. (doi:10.1677/joe.0.1800257)

Nagaraja AK, Andreu-Vieyra C, Franco HL, Ma L, Chen RH, Han DY, Zhu HF, Agno JE, Gunaratne PH, DeMayo FJ, et al. 2008 Deletion of Dicer in somatic cells of the female reproductive tract causes sterility. Molecular Endocrinology 22 2336-2352. (doi:10.1210/ me.2008-0142)

Obernosterer G, Martinez J \& Alenius M 2007 Locked nucleic acid-based in situ detection of microRNAs in mouse tissue sections. Nature Protocols 2 1508-1514. (doi:10.1038/nprot.2007.153)

Pasapera AM, Jimenez-Aguilera Mdel P, Chauchereau A, Milgrom E, Olivares A, Uribe A, Gutierrez-Sagal R \& Ulloa-Aguirre A 2005 Effects of FSH and 17beta-estradiol on the transactivation of estrogenregulated promoters and cell proliferation in L cells. Journal of Steroid Biochemistry and Molecular Biology 94 289-302. (doi:10.1016/j. jsbmb.2004.11.011)

Schmittgen KJLaTD 2001 Analysis of relative gene expression data using real-time quantitative PCR and the $2-\triangle \triangle \mathrm{CT}$ method. Methods $\mathbf{2 5}$ 402-408. (doi:10.1006/meth.2001.1262)

Sirotkin AV, Ovcharenko D, Grossmann R, Laukova M \& Mlyncek M 2009 Identification of microRNAs controlling human ovarian cell steroidogenesis via a genome-scale screen. Journal of Cellular Physiology 219 415-420. (doi:10.1002/jcp.21689)

Song T, Zhang X, Wang C, Wu Y, Dong J, Gao J, Cai W \& Hong B 2011 Expression of miR-143 reduces growth and migration of human bladder carcinoma cells by targeting cyclooxygenase-2. Asian Pacific Journal of Cancer Prevention 12 929-933.

Stefani G \& Slack F 2006 MicroRNAs in search of a target. Cold Spring Harbor Symposia on Quantitative Biology 71 129-134. (doi:10.1101/ sqb.2006.71.032)

Published by Bioscientifica Ltd. 
Stocco C 2008 Aromatase expression in the ovary: hormonal and molecular regulation. Steroids 73 473-487. (doi:10.1016/j. steroids.2008.01.017)

Teng Z, Wang C, Wang Y, Huang K, Xiang X, Niu W, Feng L, Zhao L, Yan $\mathrm{H}$, Zhang H, et al. 2015 S100A8, an oocyte-specific chemokine, directs the migration of ovarian somatic cells during mouse primordial follicle assembly. Journal of Cellular Physiology 230 2998-3008. (doi:10.1002/jcp.25032)

Wayne CM, Fan HY, Cheng X \& Richards JS 2007 Follicle-stimulating hormone induces multiple signaling cascades: evidence that activation of Rous sarcoma oncogene, RAS, and the epidermal growth factor receptor are critical for granulosa cell differentiation. Molecular Endocrinology 21 1940-1957. (doi:10.1210/ me.2007-0020)

Wei S, Gong Z, An L, Zhang T, Dai H \& Chen S 2015 Cloprostenol and pregnant mare serum gonadotropin promote estrus synchronization, uterine development, and follicle-stimulating hormone receptor expression in mice. Genetics and Molecular Research 14 7184-7195. (doi:10.4238/2015.June.29.12)

Wu XL, Cheng B, Li PY, Huang HJ, Zhao Q, Dan ZL, Tian DA \& Zhang P 2013 MicroRNA-143 suppresses gastric cancer cell growth and induces apoptosis by targeting COX-2. World Journal of Gastroenterology 19 7758-7765. (doi:10.3748/wjg.v19.i43.7758)

Xu B, Niu X, Zhang X, Tao J, Wu D, Wang Z, Li P, Zhang W, Wu H, Feng $\mathrm{N}$, et al. 2011a miR-143 decreases prostate cancer cells proliferation and migration and enhances their sensitivity to docetaxel through suppression of KRAS. Molecular and Cellular Biochemistry 350 207-213. (doi:10.1007/s11010-010-0700-6)

Xu B, Niu XB, Zhang XX, Tao J, Wu DY, Wang ZD, Li PC, Zhang W, Wu HF, Feng NH, et al. $2011 b$ miR-143 decreases prostate cancer cells proliferation and migration and enhances their sensitivity to docetaxel through suppression of KRAS. Molecular and Cellular Biochemistry 350 207-213. (doi:10.1007/s11010-010-0700-6)

Yao N, Lu CL, Zhao JJ, Xia HF, Sun DG, Shi XQ, Wang C, Li D, Cui Y \& Ma X 2009 A network of miRNAs expressed in the ovary are regulated by FSH. Frontiers in Bioscience 14 3239-3245. (doi:10.2741/3447)

Ze-An Qiu1, Guo-Ping He1 2016 MicroRNA-134 functions as a tumor suppressor gene in gastric cancer. American Journal of Translational Research 8 4320-4328.

Zhang J, Ji X, Zhou D, Li Y, Lin J, Liu J, Luo H \& Cui S 2013 miR-143 is critical for the formation of primordial follicles in mice. Frontiers in Bioscience 18 588-597. (doi:10.2741/4122)

Received in final form 7 April 2017

Accepted 25 April 2017

Accepted Preprint published online 25 April 2017 (c) 2017 Society for Endocrinology Printed in Great Britain
Published by Bioscientifica Ltd 